\title{
Investigation of Full Scale Engineering Application on Bio-pretreatment Process for Upgrading Drinking Water Quality
}

\author{
Jiajiong $X u^{1,2, a}$, Jun Ma ${ }^{1, b}$, Yuzhu Fan ${ }^{2, c}$, Shuo Zhang ${ }^{2, \mathrm{~d}}$, Min Rui ${ }^{2, \mathrm{e}}$ and Huakan \\ $\mathrm{Lu}^{2, f}$ \\ ${ }^{1}$ School of Municipal and Environmental Engineering, Harbin Institute of Technology, \\ Harbin,P.C.China \\ ${ }^{2}$ Shanghai Municipal Engineering Design Institute (Group) CO.,LTD,Shanghai, P.R.China \\ axujiajiong@smedi.com, ${ }^{\text {b }}$ majun@hit.edu.cn, ${ }^{\mathrm{c}}$ fanyuzhu@smedi.com, ${ }^{\mathrm{d}}$ zhangshuo@smedi.com, e \\ ruimin@smedi.com, ${ }^{\mathrm{C}}$ luhuakan@smedi.com
}

Keywords: ammonia nitrogen, $\mathrm{COD}_{\mathrm{Mn}}$, biological treatment, biological contact oxidation pool, filling, aeration system

Abstract. Surface water in Hangjiahu area is characterized by high content of $\mathrm{NH}_{3}-\mathrm{N}$ and organic micro-pollutants, which is in need of biological pretreatment process in water treatment plant. Based on the comparison of the characteristics of four biological pretreatment processes such as biological oxidation pond, bio-filter, biological contact oxidation tank with filler suspension, and light biological filter media, this paper focused on the application study of contact oxidation tank filled with biocarrier, which is the most common application style in this field. The practical operation and the removal efficiency of $\mathrm{NH}_{3}-\mathrm{N}$ and organic matters by contact oxidation tank filled with biocarrier in Hangjiahu area were discussed and evaluated.

\section{Introduction}

Organic contaminants in surface water supply have always been one of the major concerns in drinking water treatment, particularly in Hangjiahu area, Zhejiang Province, China. Rapid population growth, economic development and the lack of effective environmental protection often lead to serious deterioration in the quality of water resources. Sewage discharge without sufficient treatment has become the main source of organic pollution in surface water. It is estimated that more than half of the major surface water resources have been contaminated by sewage discharge. The concentration of $\mathrm{BOD}_{5}$ and $\mathrm{NH}_{3}-\mathrm{N}$ could reach as high as $3 \mathrm{mg} / 1$ or even higher than $5 \mathrm{mg} / \mathrm{l}$ respectively in some cases in China ${ }^{[1]}$. Surface water contamination by sewage discharge poses great difficulties and challenges to the capability and performance of conventional water treatment processes. Organic pollutants in the raw water worsen the problems of turbidity, odor, taste and bio-stability of treated water $^{[2]}$. In addition, organic materials and ammonia increase the chlorine demand during disinfection and the formation potentials of trihalomethane (THM) and other disinfection-by-products $(\mathrm{DBP})^{[3,4,5]}$.

Biological treatment should be considered to reduce the organic content in contaminated waters. In fact, biological treatment is widely applied in increasing nitrogen and organics removal efficiency, by biofilm ${ }^{[6,8]}$, reducing heavy metal ${ }^{[9]}$ and establishing aeration energy balance ${ }^{[10]}$. In China, the most important issue is also to gain the high quality drinking water from the contaminated drinking source water with the treatment process including biological pretreatment. The purpose of this study is to analyze the problems of biological pretreatment in practice and try to find solutions for these problems through full scale applied investigations.

\section{Methods and Materials}

Technical Characteristics of Biological Pretreatment.Ammonia is considered as one of the most difficult contaminants to be removed from water. It could also affect the performance of conventional treatment processes. Biological pretreatment is considered as the most effective technology to 
remove nitrogen [6], especially in the micro-polluted Hangjiahu river area, which is characterized by high ammonia concentration of more than $3 \mathrm{mg} / \mathrm{L}$ in average.

Biological pretreatment, which is generally set before the conventional water purification process, utilized the metabolism of microbial communities to decompose and transform contaminants in raw water, such as organic pollutants, ammonia, nitrite, iron, manganese and other inorganic pollutants. Biological pretreatment of raw water can 1) improve the coagulation performance and reduce the load of removing biodegradable organic matter by extending its biological function in conventional treatment; 2) reduce thedisinfectants doses, theformation of THMs, and other disinfection byproducts; 3) increase the biological stability of drinking water.

Biological pretreatment process had high ammonia removal efficiency. Under normal temperatures of Hangjiahu area, $80 \%$ of the ammonia in raw water can be removed. Even if the water temperature is as low as $5^{\circ} \mathrm{C}$, the removal efficiency could reach $50 \%$. In addition to high removal of ammonia, the organic matter, iron, and manganese can also be removed in the subsequent treatment process. The flocculation effect can be improved as well. With relatively simple equipment, the operation costs would be low, and generally less than $0.01 \mathrm{RMB} / \mathrm{m}^{3}$ considering about blower power consumption and some head loss. The disadvantage is that the removal efficiency is influenced by temperature. Under lower temperature condition, the removal efficiency of this process would be lower.

Style Selection of Biological Pretreatment.Biological treatment can be divided into two categories, activated sludge and biofilm. When the concentration of organic matters in micro-polluted source water is relatively low, biofilm process would be commonly used in purification process. The current pretreatment applications of the biofilm process mainly include the following types: biological filter, biological oxidation, biological contactor, fluidized bed and land treatment system through the embankment and sand dunes. The well-developed practical applications of large-scale water treatment plant biological pretreatment are: flexible packing-biological contact oxidation tank, bio-filter, biological contact oxidation tank with suspension filler and light-media biological filter.

The Elastic Packing Biological Contact Oxidation Pond.Biological contact oxidation is also known as elastic packing immersion aerated filter that filled with flexible filler in the aeration tank. The aeration of the water flowing through the packing layer provides oxygen and nutrients on the surface of filler particles to form biofilm. By contacting the water with the microorganism on the biofilm, the pollutants in water are degraded.

This method has remarkable hydrological conditions, whole surface covered with biofilm, stronger ability to adapt the change of load and less sludge generation. It is free of bulked sludge and friendly in maintenance. Under proper conditions, the residence time was generally within 1 to 2 hours, the gas to water ratio was from 0.6 to $1: 1$, the ammonia nitrogen removal efficiency was $70 \sim$ $90 \%$, the removal efficiency of $\mathrm{COD}_{\mathrm{Mn}}$ was 20 to $30 \%$.

Bio-ceramic Filter.Biological filter is often considered as a biological treatment tank. According to the raw water flow style, it can be categorized into two types: down-flow and up-flow. The inlet water of down-flow filter flows into the tank from the surface to the bottom. The biofilm formed in the filler surface can utilize nutrients from the water by degrading organic matters. On the contrary, up-flow filter's water flows from the bottom to the surface, and the filler in the filter is suspended (waving) in a semi-fluidized state. Oxygen in water is one of the most important factors for the purification of biological filter. The metabolic rate of microorganisms depends on the concentration of organic matter and dissolved oxygen. Under normal circumstances, the metabolic rate is determined by the concentration of organic matter when oxygen is abundant.

The characteristics of bio-filter include: stable performance of water treatment effect, high pollutant removal efficiency with less sludge production, resilience to the extreme environment, higher levels of organic matter degradation, easy management and operation.

Suspended Carrier Biological Contact Oxidation System.Suspended carrier has been developed to be a biological contact oxidation process for the new packing in recent years, which is characterized by: 
(A) Large specific surface area in general, ranging from several hundred to a thousand $\mathrm{m} 2 / \mathrm{m} 3$;

(B) The materials of filler are usually composed of polyethylene, polypropylene and other plastic or resin; the density of material is slightly lighter than water; the filler is easy to flip up and down with the flow in the whole pool;

(C) The filler in fluidized state is hard to agglutinate, and the aging biofilm is easily washed off by water shear, which enhance the growth of new biofilm;

(D) The filler was directly added into the pool without the aids of other accessories. The operation and management is convenient by avoiding frequent block and backwash.

Because the filler in the aeration is suspended in fluidized state, the operation would not only increase the oxygen utilization and the mass transfer efficiency, but also improve the reaction efficiency and reduce the residence time by dispersing the oxygen and water well.

Light Filtering Media Biological Filter.Light biological filter media used in filters has small particle size and spherical shape with a large specific surface area. It has the following characteristics:

(A) When water and oxygen is flowing in the same direction in micro-polluted raw water, it can operate at higher filtration rate;

(B) The materials of the filter are domestic industrial raw materials with good chemical stability, with wide variety of suppliers and cheap cost;

(C) The surface area of the filter media is more than $1000 \mathrm{~m} 2 / \mathrm{m} 3$, which is suitable for microbial growth and high pollutant load process;

(D) The particle size of the filter media is uniform with small head loss, with the whole filter layer less than $0.5 \mathrm{~m}$ under normal conditions;

(E) Because of its smaller specific gravity, the filter can float on water. The ratio of air and water is relatively low, actually within $0.4: 1$ to $1.0: 1$, and it can run at $0.4: 1$ to $0.6: 1$ in most cases.

Comparison of Biological Pretreatment Pond.The comparison of four commonly used biological oxidation process is shown in Tab.1.

Tab.1 Comparison of biological pretreatment processes

\begin{tabular}{|c|c|c|c|c|}
\hline Comparison & Elastic packing pond & Ceramic filter & $\begin{array}{l}\text { Suspended filler- } \\
\text { biological contact } \\
\text { oxidation pond }\end{array}$ & $\begin{array}{l}\text { Light media } \\
\text { biological } \\
\text { filter } \\
\end{array}$ \\
\hline $\begin{array}{c}\text { Design } \\
\text { parameters }\end{array}$ & $\begin{array}{l}\text { Residence } \\
\text { time: } 1.5 \mathrm{hr} \text {; packing } \\
\text { effective height: } \\
3.9 \mathrm{~m} \text {. Air to water } \\
\text { ratio: } 0.7 \text { to } 1.5 \text {. }\end{array}$ & $\begin{array}{l}\text { Filtration design rate: } \\
5 \mathrm{~m} / \mathrm{h} \text {; contact time: } 20 \\
\text { to } 25 \text { minutes; Air to } \\
\text { water ratio: } 0.7 \text { to } 1.5 \text {. }\end{array}$ & $\begin{array}{l}\text { Residence time: } \\
\text { 45min; filler filling } \\
\text { ratio: } 50 \% \text {; Air to } \\
\text { water ratio: } 0.7 \text { to } \\
\text { 1.5. }\end{array}$ & $\begin{array}{c}\text { Filtration } \\
\text { design rate: } \\
8 \mathrm{~m} / \mathrm{h} \text {; contact } \\
\text { time: } 19 \\
\text { minutes. Air } \\
\text { to water ratio: } \\
0.4 \text { to } 1.0 .\end{array}$ \\
\hline $\begin{array}{c}\text { Filler } \\
\text { properties }\end{array}$ & $\begin{array}{c}\text { YDT filler, } \\
\text { polyolefin } \\
\text { production, d173 } \times \\
3900 \mathrm{~mm}(\mathrm{~L}) \text {, each } \\
\text { one composed of } \\
360 \text { single-wires } \\
\text { with single wire } \\
\text { diameter of } 0.5 \mathrm{~mm} \text {. }\end{array}$ & $\begin{array}{c}\text { Ceramic particle size } \\
\mathrm{d}_{10}=3.5 \mathrm{~mm} \text {, the density: } \\
1.20 \text { to } 1.40 \text {, thickness: } \\
2 \mathrm{~m} .\end{array}$ & $\begin{array}{c}\text { Spherical or } \\
\text { cylindrical, } \mathrm{D}=2 \\
\sim 5 \mathrm{~cm} \text {; surface } \\
\text { area: } 300 \sim 500 \\
\mathrm{~m}^{2} / \mathrm{m}^{3} \text {; the density: } \\
0.95 \mathrm{~g} / \mathrm{cm}^{3} \text { or so. }\end{array}$ & $\begin{array}{c}\text { Spherical } \varphi 5 \sim \\
7 \mathrm{~mm} \text {; surface } \\
\text { area }>1000 \\
\mathrm{~m}^{2} / \mathrm{m}^{3}\end{array}$ \\
\hline $\begin{array}{c}\text { Backwash } \\
\& \text { sludge }\end{array}$ & $\begin{array}{l}\text { Backwash sludge by } \\
\text { the bottom scraper } \\
\text { with two sets of each } \\
\text { pool. Scraper works } \\
\text { once per day, with a } \\
\text { period of about } 2 \\
\text { hours. }\end{array}$ & $\begin{array}{c}\text { Backwash pumping } \\
\text { station, with air strength } \\
24 \mathrm{~L} / \mathrm{s} \cdot \mathrm{m}^{2} \text { (gas) and } 8 \sim \\
12 \mathrm{~L} / \mathrm{s} \cdot \mathrm{m}^{2} \text { (water); } \\
\text { surface dash strength of } \\
1 \sim 1.5 \mathrm{~L} / \mathrm{s} \cdot \mathrm{m}^{2} . \\
\text { Backwash was operated }\end{array}$ & $\begin{array}{l}\text { With a duckbill } \\
\text { valve at the bottom } \\
\text { of the aeration tank } \\
\text { with no sludge } \\
\text { accumulation. }\end{array}$ & $\begin{array}{l}\text { Backwash by } \\
\text { using drop } \\
\text { irrigation, } \\
\text { without extra } \\
\text { washing } \\
\text { facilities. }\end{array}$ \\
\hline
\end{tabular}




\begin{tabular}{l|c|c|c|c}
\hline & & about 7 to 10 days. & & \\
\hline Head loss & $0.4 \sim 0.6 \mathrm{~m}$ & $1.0 \mathrm{~m}$ & $0.4 \sim 0.6 \mathrm{~m}$ & $0.4 \sim 0.6 \mathrm{~m}$ \\
\hline
\end{tabular}

Considering the characteristics of the raw water in Hangjiahu region, the suspended filler biological contact oxidation process is recommended because it is a relative simple, which only takes up limited space, and has high removal efficiency of organic matters. In addition, there is no need of sludge discharge for suspended filler biological contact oxidation process. The appropriate filler and aeration systems are the key to its success.

Packing.Suspended filler of biological contact oxidation pool (hereinafter referred to as bio-pool) characterized by different surface areas for different materials. YS-type suspended carrier has the highest surface area because of its special leaf structure, which benefits the development of biofilm and thus has better water treatment performance. However, it is more likely to breed aquatic organisms and cause congestion with the overgrowth of biomass. During installation, suspended carrier can be added to the bio-pool directly without adjustment, support brackets and other appendages, which can reduce the expense of installation and require less maintenance. In order to prevent the suspended filler from moving with the flow, additional vertical baffles and stainless steel sub-frame grilles should be installed and high quality suspended filler should be used to prevent the damage caused by collision.

In addition, the suspension filler was fluidized with the rotation and frequent collisions. It can reduce the flow resistance and has full access to dissolved oxygen and organic pollutants, which are conducive to microbial growth and slough off, to maintain biofilm activity and quantity. Because of the fact that the filler being fixed in the pool, the aging of YDT biofilm is not easy to fall off.

Aeration System.Aeration system of biological pretreatment provides adequate oxygen source. Its layout and selection is very important. In existing water plant, the common choice is the closed circular rubber sheet microporous aeration, perforated pipe aeration and duckbill valve perforated aeration tube.

Generaly, the oxygen transfer efficiency of closed circular rubber sheet microporous aeration is higher than that of perforated pipe aeration. However, some microporous aerations can not stand over 5 years because of their limitation to resist extreme gas pressure and temperature. Meanwhile, disturbance on the water body is weak, microporous aerations are easily integrated by sludge congestion. The expense of the porous aeration is also higher. The oxygen transfer efficiency of the perforated pipe aeration is lower, but the layout and management are simpler and cheaper. Disturbance of duckbill valve aeration system on the water body is stronger with better mass transfer efficiency, but the price is higher. The result of duckbill-type head cloth coarse aeration is shown in Fig.1. The aeration on damaged condition is shown in Fig.2. Large amounts of gas from the aeration system flowed out into the water, which disturbed air dispersion and oxygen transfer efficiency.

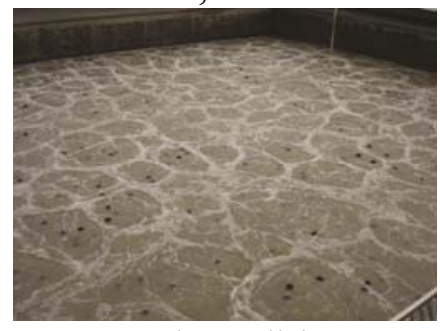

Fig.1 Aeration on good condition

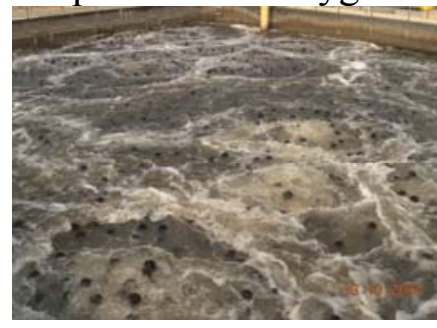

Fig.2 Aeration on damaged condition

\section{Results and Discussion}

Biological Contact Oxidation Pond in N WTP.The nitrogen removal efficiency in biological contact oxidation pond of N WTP is shown in Fig. 3. 


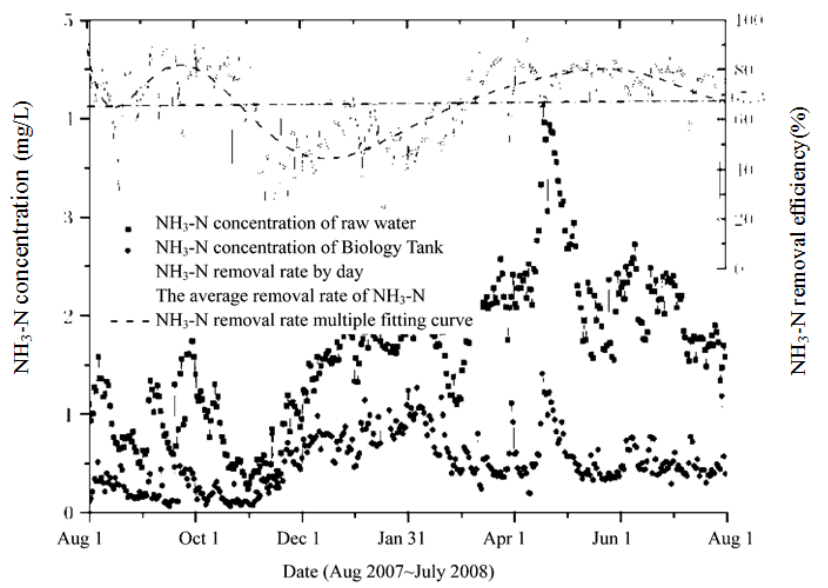

Fig. $3 \mathrm{NH}_{3}-\mathrm{N}$ removal efficiency of biological contact oxidation pond in water treatment plant $\mathrm{N}$

The ammonia removal of biological pond was affected mainly by water temperature. When water temperature was high $\left(>10^{\circ} \mathrm{C}\right)$ from March to October, the removal efficiency of ammonia nitrogen was $75.58 \%$ in average. When the water temperature was low $\left(5 \sim 10{ }^{\circ} \mathrm{C}\right)$ from November to next February of the following year, the average ammonia removal efficiency of biological pool was about $50.5 \%$. The maximal and average concentrations of ammonia were $4.14 \mathrm{mg} / \mathrm{L}$ and $1.62 \mathrm{mg} / \mathrm{L}$ in raw water for the past year, respectively. The average removal efficiency of biological nitrogen pool was $67.3 \%$ with the average ammonia in bio-tank effluent about $0.51 \mathrm{mg} / \mathrm{L}$. The ammonia removal performance was relatively stable.

The turbidity removal efficiency in biological tank of N WTP is shown in Fig. 4.

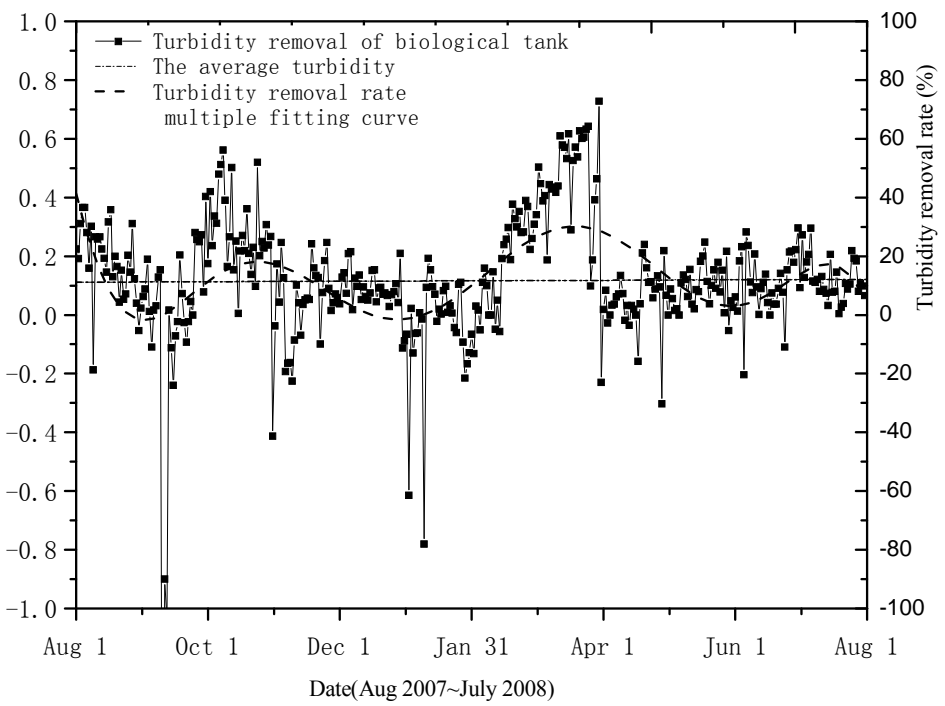

Fig. 4 Turbidity removal efficiency of biological contact oxidation pond in water treatment plant $\mathrm{N}$

In average, $13.3 \%$ turbidity was removed in biological pool over the past year. The fitting curve showed that the removal efficiency of bio-pool turbidity kept flocculating around $13.3 \%$ on the period of average 4 months, which may be related to the biological growth cycle.

The $\mathrm{COD}_{\mathrm{Mn}}$ removal efficiency in biological tank of N WTP is shown in Fig. 5. The organic pollution of raw water in N WTP was heavier. The annual average $\mathrm{COD}_{\mathrm{Mn}}$ concentration of the raw water was $6.65 \mathrm{mg} / \mathrm{L}$. After biological treatment pond, the average concentration of $\mathrm{COD}_{\mathrm{Mn}}$ in bio-pool effluent was $6.16 \mathrm{mg} / \mathrm{L}$ with the removal efficiency of $7.4 \%$ over one year. When the water temperature was low from January to April, the $\mathrm{COD}_{\mathrm{Mn}}$ removal of bio-pool was relatively high. With $10 \%$ to $15 \%$ removal of $\mathrm{COD}_{\mathrm{Mn}}$, the ammonia nitrogen removal efficiency was relatively low and the carbon source absorption of biofilm increased. 


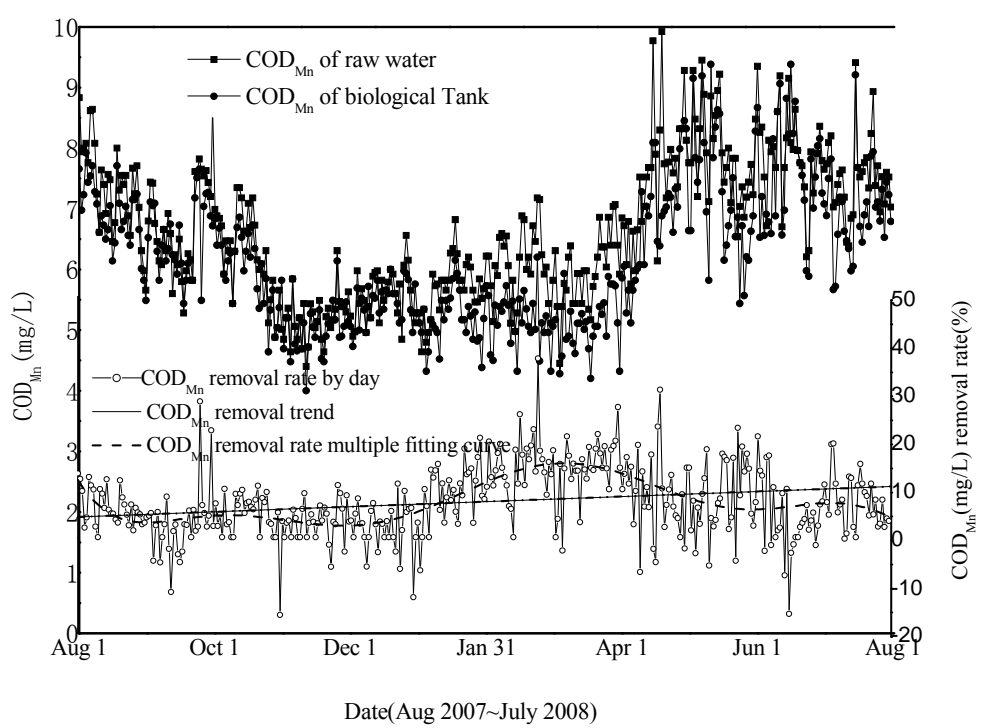

Fig. 5 COD $_{\mathrm{Mn}}$ removal efficiency of biological contact oxidation pond in water treatment plant $\mathrm{N}$ The iron and manganese removal efficiency in biological tank of N WTP are shown in Fig. 6 and Fig. 7.

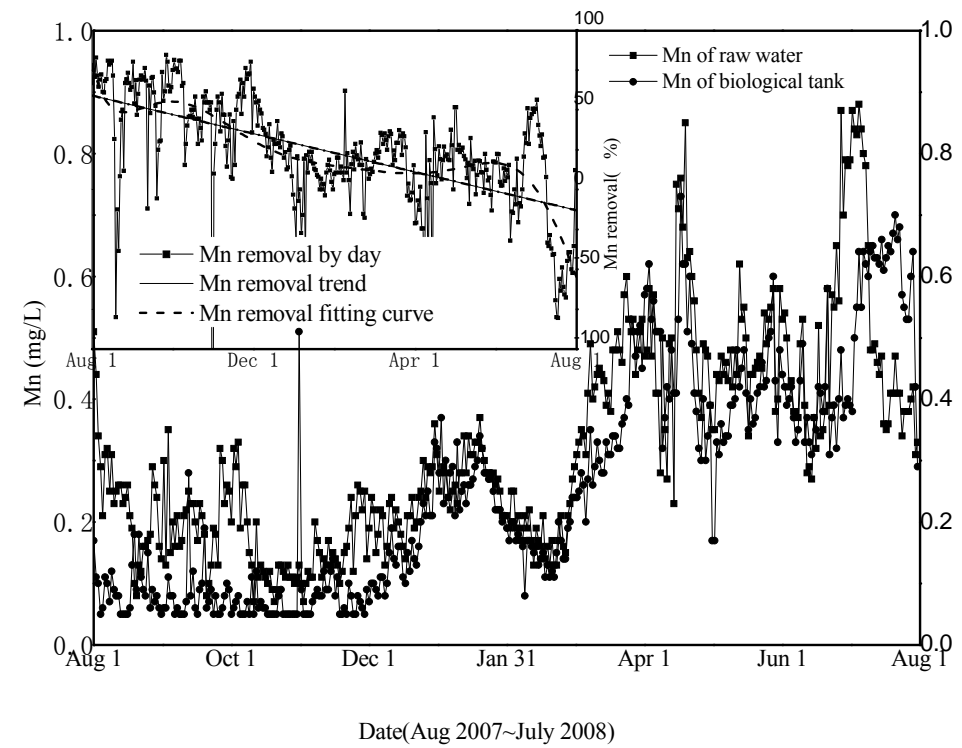

Fig. 6 Manganese removal efficiency of biological contact oxidation pond in water treatment plant $\mathrm{N}$

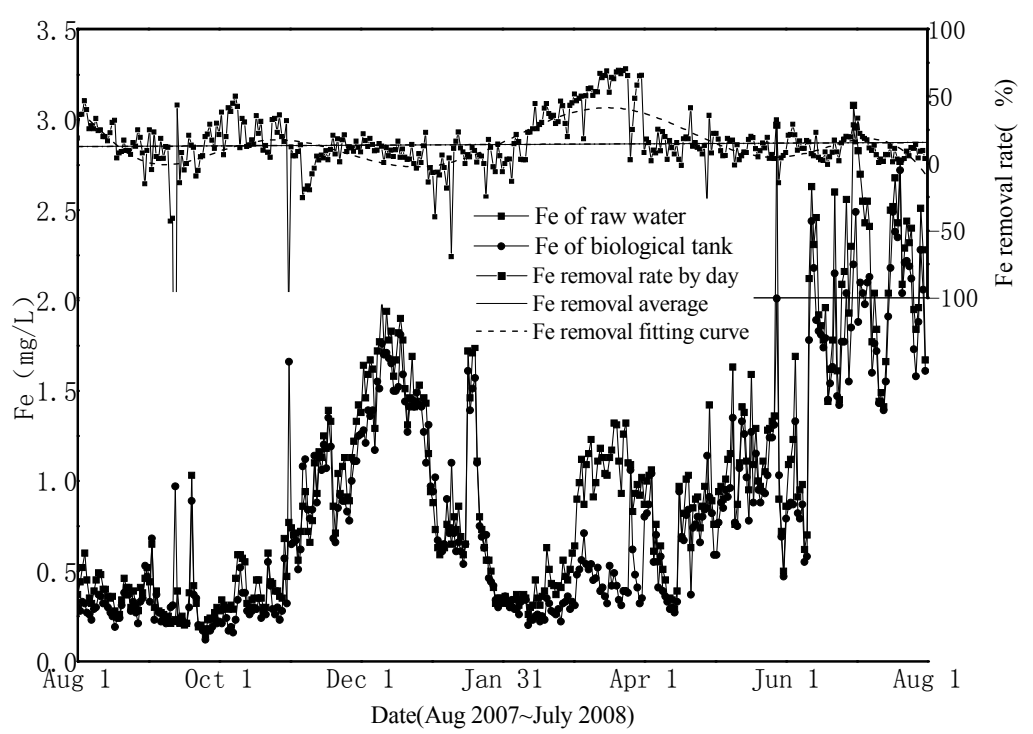

Fig. 7 Iron removal efficiency of biological contact oxidation pond in water treatment plant $\mathrm{N}$ 
The average removal of manganese is $20 \%$, and the average removal efficiency of iron is $15 \%$. The manganese removal efficiency in biological tank of N WTP was gradually decreased, from $60 \%$ at the beginning of the operation to around $-20 \%$ in July 2008. It indicates that the manganese is removed mainly by biofilm adsorption of suspending filler at the beginning. When the adsorption reached saturation, manganese adsorbed on suspended filler begin parsing, and the removal of manganese becomes negative, then the bio-pool should be cleaned. The iron is removed by way of sedimentation in the bio-pool. The iron removal efficiency in biological tank of N WTP is relatively stable with around $15 \%$ of fluctuations for a period of four months with similar laws of turbidity removal.

Biological Contact Oxidation Pond in H WTP.The maximal, minimal and average concentration of ammonia of the raw water in H WTP was $8.75,0.94$, and $3.81 \mathrm{mg} / \mathrm{L}$ respectively for the past one and a half years. The nitrogen after biological pool dropped significantly with the effluent ammonia concentration from maximum $4.23 \mathrm{mg} / \mathrm{L}$ to minimum $0.02 \mathrm{mg} / \mathrm{L}$, and the average ammonia concentration of $0.86 \mathrm{mg} / \mathrm{L}$. Fig. 8 shows the removal efficiency of $\mathrm{NH}_{3}-\mathrm{N}$ in the past one and a half years.

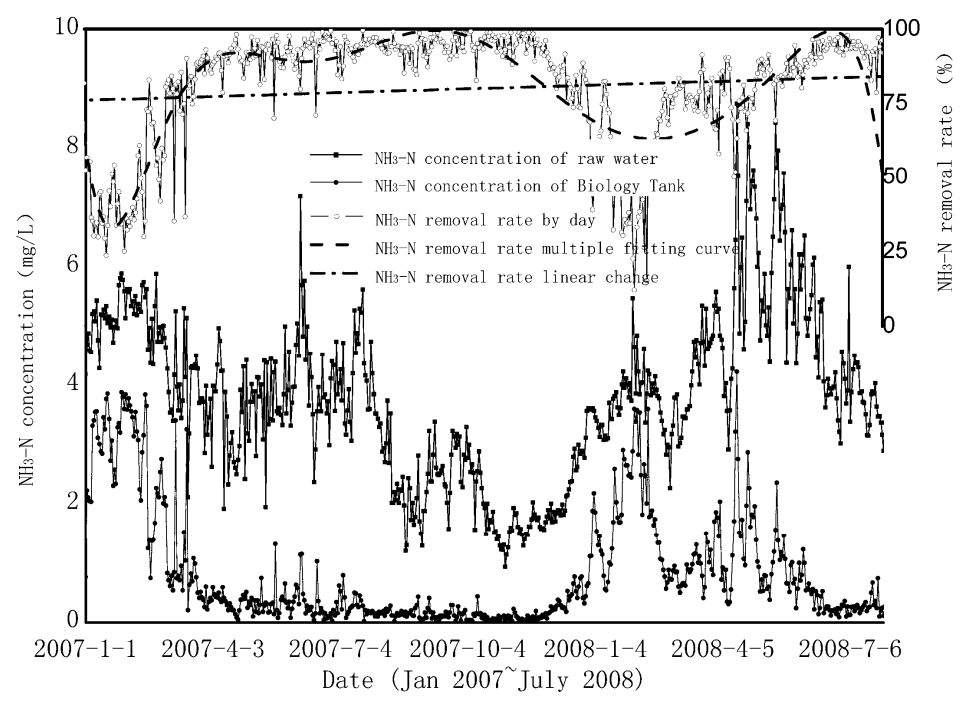

Fig. $8 \mathrm{NH}_{3}-\mathrm{N}$ removal efficiency of biological contact oxidation pond in water treatment plant $\mathrm{H}$

The average removal efficiency of $\mathrm{NH}_{3}-\mathrm{N}$ in Contact tank was about $80.2 \%$, and the ammonia nitrogen removal was influenced by temperature. When the temperature was low (December to next March), the ammonia concentration of raw water was high, but the biological activity under low temperatures was lower, which resulted in higher ammonia concentration in the effluent with only about $60 \%$ ammonia nitrogen removal efficiency. However, when the temperature was high (April to November), bio-pool can maintain high ammonia removal efficiency at more than $90 \%$, which would reduce the burden of follow-up treatment.

In addition, when $\mathrm{NH}_{3}-\mathrm{N}$ concentration in the raw water suddenly raised or fell, the removal efficiency decreased, indicating the obvious effect of rapidly changing load on the treatment performance. If the influent concentration of $\mathrm{NH}_{3}-\mathrm{N}$ was stable, and then the removal efficiency could maintain at around $90 \%$. The $\mathrm{NO}_{2}-\mathrm{N}$ average removal efficiency of the contact tank was $82 \%$, but it was unstable, especially in the raw water with more than $4.0 \mathrm{mg} / \mathrm{L}$ ammonia. It was found that the concentration of $\mathrm{NO}_{2}-\mathrm{N}$ in the effluent was higher than the influent from time to time, which may be attributed to the competition between nitrifying bacteria and denitrifying bacteria.

The turbidity removal efficiency in biological contact oxidation pond of H WTP is shown in Fig. 9. The maximal, minimal and average values of turbidity in raw water of H WTP were 112.4NTU, 8.2NTU, and $34.1 \mathrm{NTU}$ respectively over 1.5 year. The corresponding turbidity values for biological pond water were $89.6 \mathrm{NTU}, 2.64 \mathrm{NTU}$ and $29.8 \mathrm{NTU}$, respectively. It is shown in Fig. 2 that the turbidity removal efficiency of biological pond is relatively stable. The average removal efficiency was about $9 \%$ without significant change during the whole study period, which indicated that there 
was not any accumulation of the biological sludge in the pool, and the turbidity removal should be mainly caused by the biological action.

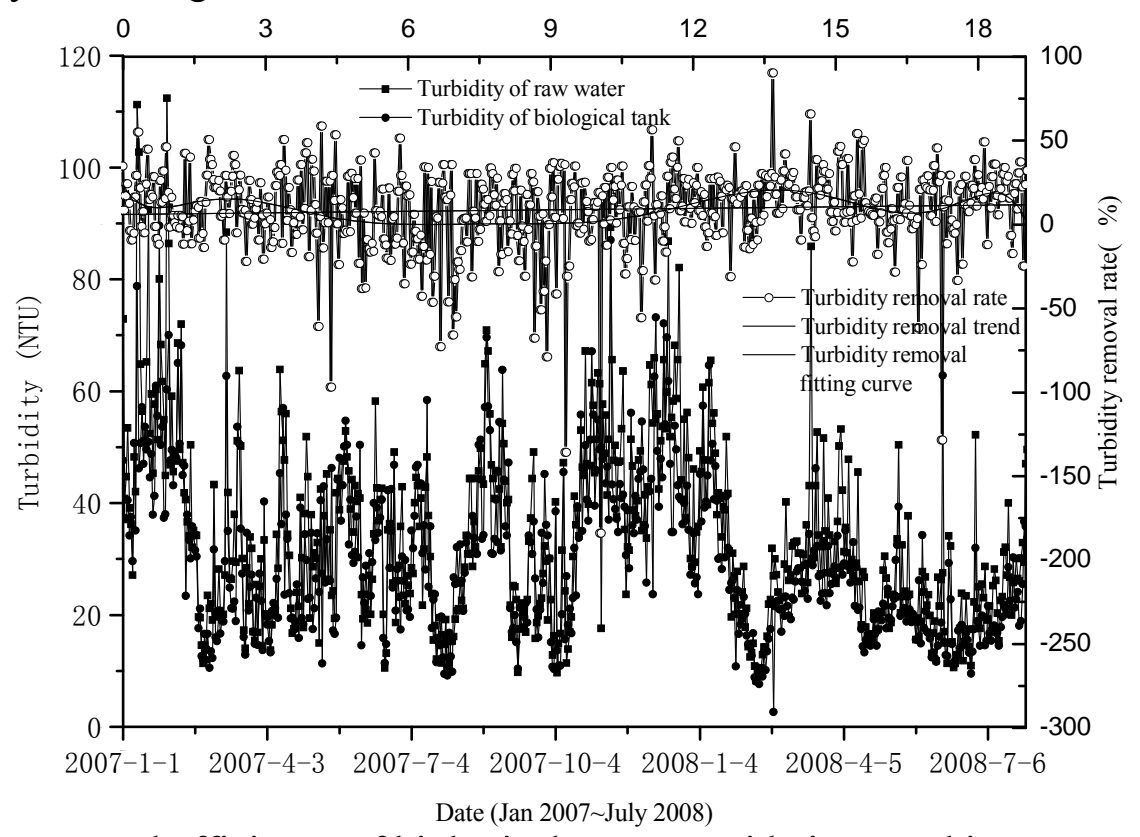

Fig. 9 Turbidity removal efficiency of biological contact oxidation pond in water treatment plant $\mathrm{H}$

The $\mathrm{COD}_{\mathrm{Mn}}$ removal efficiency in biological tank of H WTP is shown in Fig. 10. The maximum, minimal and average values of $\mathrm{COD}_{\mathrm{Mn}}$ value of the $\mathrm{H}$ WTP raw water over past 1.5 year were $13.68 \mathrm{mg} / \mathrm{L}, 5.72 \mathrm{mg} / \mathrm{L}, 9.32 \mathrm{mg} / \mathrm{L}$; the maximum, minimal and average values of $\mathrm{COD}_{\mathrm{Mn}}$ in bio-tank effluent were $12.96 \mathrm{mg} / \mathrm{L}, 4.78 \mathrm{mg} / \mathrm{L}, 8.38 \mathrm{mg} / \mathrm{L}$, the average $\mathrm{COD}_{\mathrm{Mn}}$ removal efficiency of raw water in contact tank was $9.8 \%$. It was found that the $\mathrm{COD}_{\mathrm{Mn}}$ removal of biological pool was related to $\mathrm{COD}_{\mathrm{Mn}}$ concentration. With higher initial $\mathrm{COD}_{\mathrm{Mn}}$ concentration, the process would get higher corresponding removal efficiency. The removal efficiency of organic matter increased along with the running time of the biological pool.

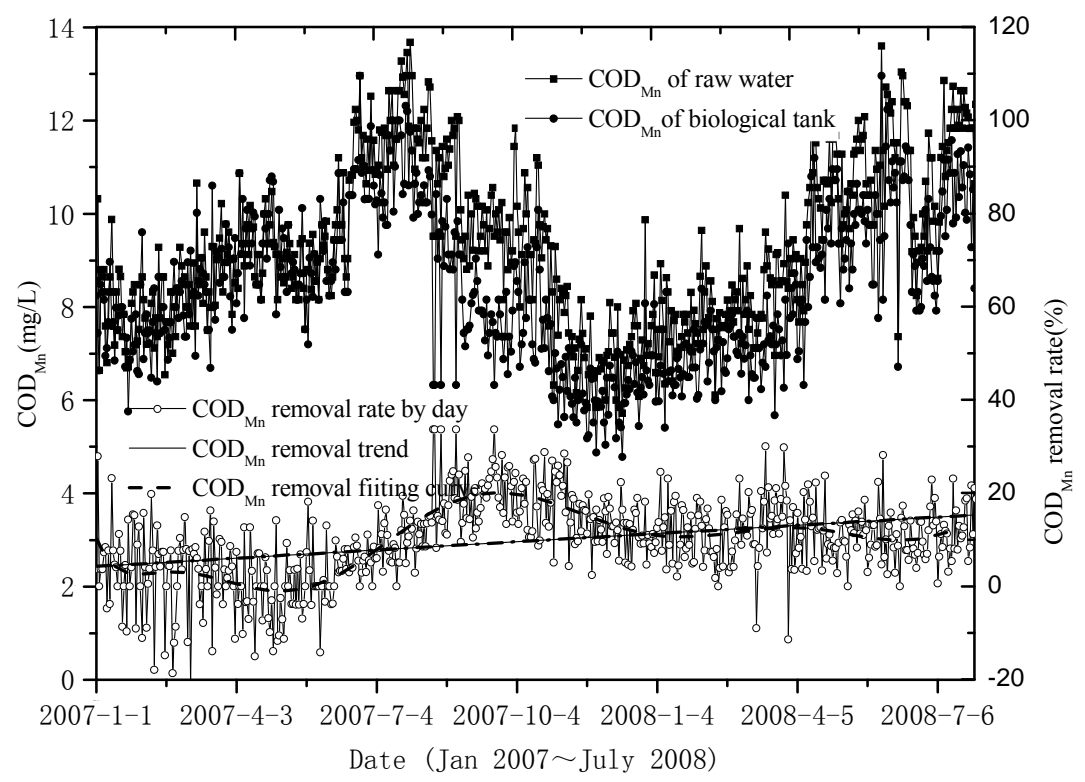

Fig. $10 \mathrm{COD}_{\mathrm{Mn}}$ removal efficiency of biological contact oxidation pond in water treatment plant $\mathrm{H}$

The manganese removal efficiency in biological tank of H WTP is shown in Fig.11. The maximum, minimal and average values of manganese value of the H WTP raw water were $0.91 \mathrm{mg} / \mathrm{L}, 0.11 \mathrm{mg} / \mathrm{L}$, $0.42 \mathrm{mg} / \mathrm{L}$; the average removal efficiency was $54.7 \%$. The maximum, minimal and average values of iron value of the H WTP raw water were $3.75 \mathrm{mg} / \mathrm{L}, 0.11 \mathrm{mg} / \mathrm{L}, 1.77 \mathrm{mg} / \mathrm{L}$, the average iron removal efficiency of raw water in bio-pool was about $10 \%$, similar to the effect of the removal $\mathrm{COD}_{\mathrm{Mn}}$. 


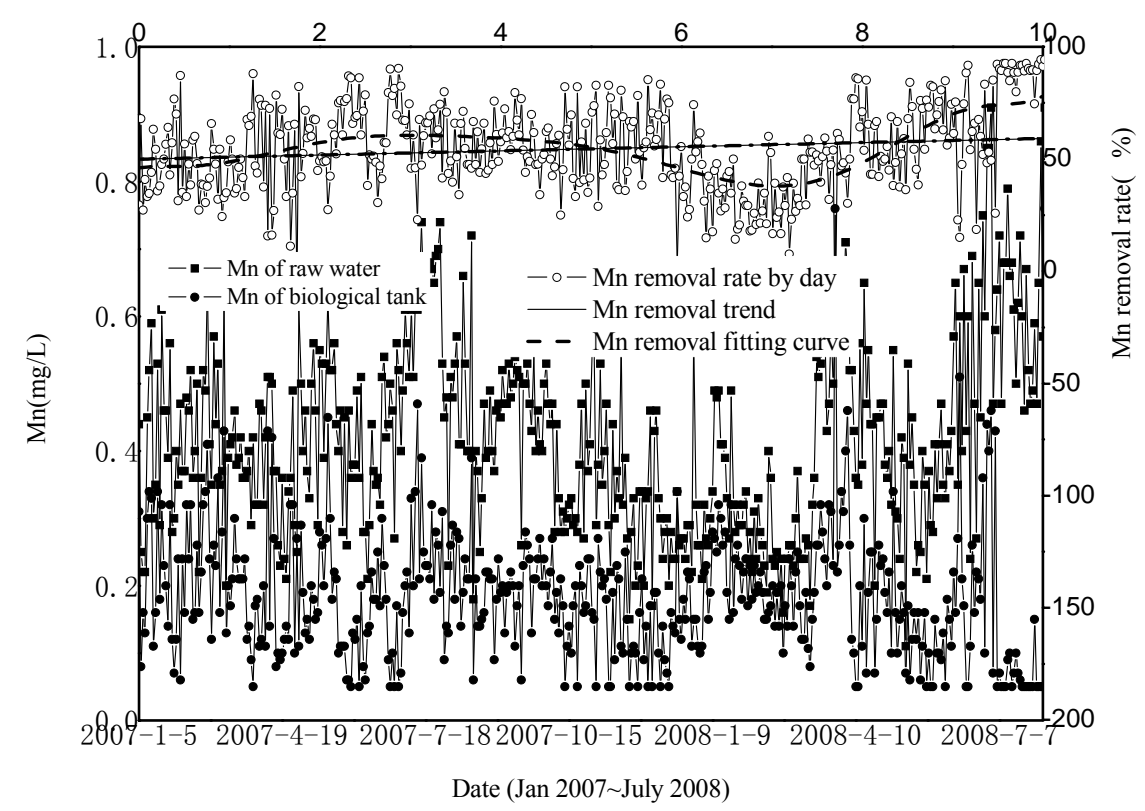

Fig. 11 Manganese removal efficiency of biological contact oxidation pond in water treatment plant $\mathrm{H}$

According to the operating data of some water biological pretreatment in Hangjiahu area over the years, some indicators and the specific results of several typical water plants were compared in Table 2.

Table 2 The operating parameters in Hangjiahu's waterworks

\begin{tabular}{c|c|c|c|c|c}
\hline Waterworks & $\mathrm{S}$ & \multicolumn{2}{|c|}{$\mathrm{G}$} & $\mathrm{H}$ & $\mathrm{N}$ \\
\hline Filler types & YDT & YDT & YS & LT & LT \\
\hline $\begin{array}{c}\text { Ammonia nitrogen removal } \\
\text { efficiency (\%) }\end{array}$ & $50-90$ & $50-90$ & $70-90$ & $70-90$ & $50-90$ \\
\hline $\begin{array}{c}\text { Maximum removal of } \\
\text { ammonia nitrogen ( mg/L) }\end{array}$ & 3.5 & 3.3 & 3.1 & 3.8 & 2.8 \\
\hline $\begin{array}{c}\text { Nitrite removal efficiency } \\
(\%)\end{array}$ & 6.5 & 11.3 & 12.5 & 6.2 & 8.2 \\
\hline Iron removal efficiency (\%) & 22 & 30.5 & 30.7 & 10 & 15 \\
\hline $\begin{array}{c}\text { Manganese removal } \\
\text { efficiency \%) }\end{array}$ & 10 & 12 & 15 & 54.7 & 20 \\
\hline Color removal efficiency (\%) & 11 & 11.3 & 10.9 & 12 & 10 \\
\hline $\begin{array}{c}\text { Turbidity removal efficiency } \\
(\%)\end{array}$ & 33 & 49 & 30.3 & 9 & 12 \\
\hline
\end{tabular}

\section{Conclusions}

At normal temperature, the biological pretreatment process of raw water was the most effective way to remove $\mathrm{NH}_{3}-\mathrm{N}$. In Hangjiahu district, the application of suspended filler bio-contact oxidation tank was very common. There are different advantages and disadvantages of the fillers of biological pretreatment. So for different raw waters, the design of related pool structure and aeration facilities should be further optimized to deal with sludge, backwash and spread of aquatic animals. The application of biological pretreatment in Hangjiahu region demonstrated that the biological contact oxidation tank could remove ammonia from about $50 \%$ to $80 \%$. Meanwhile, $\mathrm{COD}_{\mathrm{Mn}}$, iron and manganese would be removed to a certain level. The sludge deposition and filler loss should be noticed during the application of suspended filler biological contact oxidation tank. It is important to optimize the gas and water distribution, packing design and operation management. Measures should 
be taken to prevent the problems of aquatic animal proliferation and material corrosion in the application of biological pretreatment pond.

\section{Acknowledgements}

The author gratefully acknowledges the assistance of Ms. Yang Qian of Tongji University.This work was financially supported by the key Special Program on the S\&T for the Pollution Control and Treatment of Water Bodies (2012ZX07403003) and Shanghai Municipal Engineering Design Institute (Group) Co., Ltd. (K2015K039).

\section{References}

[1] Q. Xia, Y.Q. Chen, S.Z. Wu, X.Y. Guo, J. Liu: The guide for Chinese surface water environment Standard(Chinese Environmental Science Publishing, Beijing 2000).

[2] E. Carraro, E. Bugliosi, L. Meucci, C. Baiocchi, G. Gilli: Water Research Vol. 34(2000), p.3042-3054.

[3] H.P. Chu, J.H.C. Wong, X.Y. Li: Water Science Technology, Vol.46(2002), p.401-406.

[4] R.P. Galapate, E. Agustiani, A.U. Baes, Ito, M. K. Okada: Water Research,33(1999), p.131-136.

[5] R.P. Galapate, A.U. Baes, Ito, K. Iwase, M.K. Okada: Water Research,33(1999),p.2555-2560.

[6] X.H. Zhang, J.T. Zhou, H.Y. Guo, Y.Y. Qu, G.F. Liu, L.H. Zhao: Process Biochem,42(2007),p.620-626.

[7] J.Q. Sang, X.H. Zhang, L.Z. Li, Z.S. Wang: Water Research,37(2003),p.4711-4718.

[8] V. Lazarova, J. Manem: Water Research, 29(1995) ,p.2227-2245.

[9] C.C. Viggi, F. Pagnanelli, A. Cibati, D. Uccelletti, C. Palleschi, L.Toro: Water Research, 44(2010),p.151-158.

[10]B. Verrecht, S.Judd, G. Guglielmi, C. Brpols, J.W. Mulder: Water Research, 42(2008),p.4761-4770. 